\section{Scientific journal}

PHYSICAL AND MATHEMATICAL EDUCATION

Has been issued since 2013.

Науковий журнал

ФІЗИКО-МАТЕМАТИЧНА ОСВІТА

Видається з 2013.
ISSN 2413-158X (online)

ISSN 2413-1571 (print)

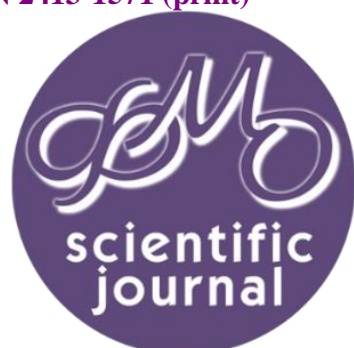

Яковлєва О.М., Каплун В.М., Анісімова Т.Л. Деякі нотатки щодо введення в курсі математики 5 класу алгебраїчного методу розв'язування текстових задач. Фізико-математична освіта. 2021. Випуск 1(27). С. 107-111.

Yakovlieva O., Kaplun V., Anisimova T. Some notes on the introduction of the algebraic method of solving text tasks in the 5th grade mathematics course. Physical and Mathematical Education. 2021. Issue 1(27). P. 107-111.

DOI 10.31110/2413-1571-2021-027-1-017

Удк 372.851

О.М. Яковлєва

Державний заклад «Південноукраїнський національний педагогічний університет імені К. Д. Ушинського», Україна

Yakovlieva.ON@pdpu.edu.ua ORCID: 0000-0003-0750-9769

B.М. Каплун

Одеська загальноосвітня школа № 68 I-III ступенів, Україна viktoriyakaplun9@gmail.com

Т.л. Анісімова

Одеська загальноосвітня школа № 30 I-III ступенів, Україна zgamatatjana@gmail.com

\title{
ДЕЯКІ НОТАТКИ ЩОДО ВВЕДЕННЯ В КУРСІ МАТЕМАТИКИ 5 КЛАСУ АЛГЕБРАЇЧНОГО МЕТОДУ РОЗВ'ЯЗУВАННЯ ТЕКСТОВИХ ЗАДАЧ
}

АНОТАЦІЯ

Формулювання проблеми. Характеризуючи навчальний зміст курсу математики 5-9 класів, можна стверджувати, що текстові задачі займають в ньому істотне місие. Основними методами розв'язування текстових задач в 5-му класі $\epsilon$ арифметичний та алгебраїчний методи. В статті розглядається співвідношення в шкільному курсі математики 5 класу арифметичного та алгебраїчного методів, їх ролі в розвитку мислення учнів та відповідний зміст підручників математики 5 класу.

Матеріали та методи. Використано методи аналізу, синтезу, порівняння, опису одержаних результатів дослідження, узагальнення. Застосовано теоретичні методи дослідження, по'вязані з аналізом чинних навчальних програм з математики, підручників математики 5-го класу, відповідних інформаційних джерел. Узагальнено власний педагогічний досвід та спостереження.

Результати. У статmі обговорюються основні методи розв'язування текстових задач в курсі математики 5-го класу Зазначено, що розвиток формування вмінь розв'язувати текстові задачі переходить від арифметичного методу у початковій школі до переважно алгебрайчного методу у 5-му класі основної школи. 3'ясовано, що в підручниках 5-го класу введення алгебраїчного методу розв'язування задач істотно відрізняється.

Висновки. Виходячи з власного досвіду, обговорень з вчителями математики вищезазначених питань, можемо стверджувати, що спроби одразу і повністю переключити учнів 5-го класу на алгебраїчний метод розв'язування задач вдаються невдалими. Формування в учня 5-го класу навичок роботи з алгебраїчним методом є довгим та трудомістким процесом як для учня, так і для вчителя. Між арифметичним та алгебраїчним методом розв'язування задач потрібно проводити паралелі, щоб учні не вважали ці методи відірваними один від одного. Вважаємо, що у 5-6 класах потрібно обов'язково продовжувати розв'язувати задачі обома методами.

КлючОвІ СлОвА: основна школа, текстові задачі, арифметичний метод, алгебраїчний метод.

ВСТУП

Текстові (сюжетні) задачі посідають чільне місце курсі математики початкової школи. За С. Скворцовою (Скворцова, 2006) під сюжетною задачею розуміють математичну задачу, в якій описується кількісний бік реальних процесів, явищ, ситуацій, і міститься вимога знайти шукану величину за даними в задачі величинами та зв'язками між ними. Згідно з програмою (Програма, 2018), у 1-му і 2-му класах формується поняття про задачу (просту або складену), ї структурні елементи, сутність процесу розв'язування задач; основним завданням $€$ набуття учнями загального вміння розв'язувати сюжетні задачі. Починаючи з 3-го класу головним завданням виступає формування в учнів уміння розв'язувати 
задачі певних типів, удосконалюється загальне вміння розв'язувати задачі. Сюжетні задачі, особливо практично зорієнтовані, забезпечують зв'язок математики із реальним життям дитини, виявлення учнем своєї компетентності (Скворцова, 2006).

У процесі розв'язування текстових задач реалізуються навчальні, розвивальні та виховні цілі: в учнів формується система арифметичних навичок і вмінь, спроможність застосовувати при розв'язуванні задачі загальнонаукові методи пізнання (аналіз, синтез, аналогію, абстрагування, конкретизацію, узагальнення тощо), уміння будувати математичні моделі текстових задач, спроможність самостійно робити висновки. Текстові задачі пов'язують теорію з практикою, розширюють уявлення дитини про життя, удосконалюють практичні навички підрахунку. Ці питання докладно вивчено М. Богдановичем, Н. Істоміною, А. Пишкало, С. Скворцовою, Л. Фрідманом та ін.

Курс математики основної школи логічно продовжує реалізацію завдань математичної освіти учнів, розпочату в початкових класах, розширюючи і доповнюючи ці завдання відповідно до вікових і пізнавальних можливостей школярів. В основу побудови змісту й організації процесу навчання математики покладено компетентнісний підхід, відповідно до якого кінцевим результатом навчання предмета є сформовані певні компетентності як здатності учня успішно діяти в навчальних і життєвих ситуаціях і нести відповідальність за свої дії (Програма, 2017). Виокремлено математичну компетентність, що передбачає здатність розвивати й застосовувати математичне мислення для вирішення широкого спектру проблем у повсякденному житті; моделювання процесів та ситуацій із застосуванням математичних відношень та вимірювань, усвідомлення ролі математичних знань та вмінь в особистому і суспільному житті людини.

Метою математичної освітньої галузі $€$ формування математичної компетентності у взаємозв'язку $з$ іншими ключовими компетентностями через розкриття розумових здібностей дитини, розвиток її знань, умінь і способів дій, наукового світогляду і культури мислення для успішної діяльності впродовж життя.

Характеризуючи навчальний зміст курсу математики 5-9 класів, можна стверджувати, що текстові задачі (сюжетні, задачі прикладного та практичного змісту) займають істотне місце. Основними функціями цих задач є розвиток логічного мислення учнів, спроможність будувати математичну модель задачі, розв'язувати задачу та вміння пояснювати здобуті результати.

\section{МЕТОДИ ДОСЛІДЖЕННЯ}

Використано такі методи як аналіз, синтез і порівняння наукових і методологічних джерел, опис одержаних результатів дослідження, узагальнення. Застосовано теоретичні методи дослідження, по'вязані з аналізом чинних навчальних програм з математики початкової та основної школи стосовно розвитку вмінь розв'язувати текстові задачі різними методами, підручників математики 5-го класу для порівняння введення алгебраїчного методу розв'язування текстових задач, відповідних інформаційних джерел. У статті узагальнено авторський педагогічний досвід та спостереження.

\section{ТЕОРЕТИЧНІ ОСНОВИ ДОСЛІДЖЕННЯ}

Відповідно до програми (Програма, 2018), уявлення про процес розв'язування задачі формується як перехід від текстової моделі (текст задачі) до схематичної (короткий запис, схематичний рисунок), а далі - до математичної (вираз, рівняння). Процес розв'язування задачі передбачає аналіз їі умови, подання результатів цього аналізу у вигляді допоміжної моделі - короткого запису (схематично, таблицею, кресленням), схематичного рисунка тощо; пошук шляхів і складання плану розв'язування задачі, створення математичної моделі задачі. В Держстандарті зазначено, що здобувач/здобувачка освіти: виокремлює проблеми та досліджує ситуації, які можна розв'язувати із застосуванням математичних методів; моделює процеси і ситуації, створює стратегії, плани дій для розв'язання проблемних ситуацій; критично оцінює процес та результат розв'язання проблемних ситуацій; мислить математично, володіє математичною мовою.

Тепер розглянемо методи розв'язування задач, які визначають як сукупність прийомів розумової діяльності або логічних математичних дій та операцій, за допомогою яких розв'язується великий клас задач. У методичній літературі виділено як основні методи розв'язування текстових задач арифметичний та алгебраїчний методи. 3 арифметичним методом розв' язування задач учні починають своє знайомство в початковій школі та використовують його до 5 класу включно. Цей метод передбачає розв'язування задачі по діям. Кожна дія - відповідь на запитання, яке ставить вчитель для того, щоб привести учнів до правильного розв'язку. Розв'язувати текстові задачі алгебраїчним методом учні почитають у 5 класі основної школи. Під час вивчення теми «Натуральні числа і дії з ними. Геометричні фігури і величини» учні знайомляться з новим методом розв'язування текстових задач за допомогою складання та розв'язування відповідного алгебраїчного рівняння. При подальшому вивченні курсу математики 5-го класу в кожній темі зустрічаються текстові задачі, розв'язування яких зводиться до розв'язування рівнянь. В 5-6-х класах алгебраїчний метод стає пріоритетним, поступово витісняючи арифметичний.

\section{РЕЗУЛЬТАТИ ДОСЛІДЖЕННЯ}

До кінця 60-х рр. XX століття арифметичний метод розв'язування задач був домінуючим у радянській школі: історично метою навчання учнів арифметиці було засвоєння визначеної кількості умінь виконувати обчислення, що було пов'язано з необхідністю проводити на практиці певні розрахунки. Задачі в підручниках «Арифметика для 5-6 классов» було класифіковано за способом розв'язування (задачі на знаходження чисел за сумою, різницею, кратному відношенню, задачі на знаходження числа за його дробом, знаходження дробу від числа тощо). Підручники арифметики для 5-6 класів до кінця 60-х років не містили алгебраїчного методу розв'язування задач, задачі розв'язувались виключно арифметичним методом, проте, наприкінці розв'язання складався відповідний буквений вираз (Рис. 1). 
5. Во сколько дней 6 рабочих, работая по 7 дасов в день, могут оштукатурнть стену длиной $128, \mu$ н высотой $3,5 \mu$, если каждын̆ из них может оштукатурить в час приблизительно $3 \frac{1}{3}$ кв. $M$ ?

Ллан решения:

1) Чему равна площадь стены?

2) Сколько квадратных метров могут оштукатурить в день все рабочне вместе?

3) Сколько потребуется дней дютя выполнения работы?

$$
\text { Р ешени н: }
$$

1) $128 \cdot 3,5=448(\kappa 8 . \mu)$;

2) $3 \frac{1}{3} \cdot 7 \cdot 6=140$ (KB. $\left.M\right)$;

3) $448: 140 \approx 3$ (дня)

Числовая формула будет иметь внд

$$
(128 \cdot 3,5):\left(3 \frac{1}{3} \cdot 7 \cdot 6\right) \approx 3 .
$$

Обозначая данкые буквами, можем записать:

$$
t=\frac{a \cdot b}{m \cdot n \cdot p} \text {. }
$$

Сравнение числовой формулы с буквенной очень полеэно для уяснения процесса решения.

-

Рис. 1. Фрагмент підручника з арифметики для 5-6 класів (автор І. Н. Шевченко, 1966)

3 часом арифметичний метод отримав досить жорстку критику. Так, в 1946 році І.Арнольд опублікував статтю (Арнольд, 1946), в якій наголосив, що процес навчання розв'язуванню задач зводиться до пасивного запам'ятовування невеликої кількості стандартних прийомів розв'язування та впізнання за певними ознаками: «Учеников... знакомят с соответствующими «типами» задач, причем обучение решению задач сплошь и рядом сводится к рецептуре и «натаскиванию», к пассивному запоминанию учениками небольшого числа стандартных приемов решения и узнаванию по тем или иным признакам, какой из них надо применить в том или ином случае. В итоге полная беспомощность и неспособность ориентироваться в самых простых арифметических ситуациях, при решении чисто практических задач...».

У 60-х рр XX століття в СРСР проводилась реформа математичної освіти, що було обумовлено переходом до загальної середньої освіти. В зв'язку з цим виникла необхідність реформування та модернізації середньої освіти в цілому та навчальних програм і підручників математики зокрема. Значна кількість математиків і методистів вважали, що 3 програми математики необхідно видалити застарілі розділи та почати будувати шкільну математику на науковій основі: зробити підґрунтям шкільної математики теоретико-множинний і функціональний підхід. Це означало, що при -розв' язуванні текстових задач необхідно почати широко використовувати методи алгебри, і як можна раніше. Після реформи кількість навчальних годин на розв'язування задач арифметичним методом значно скоротили, перевагу було надано алгебраїчному методу, пов'язаному з поняттям функції, складанням і розв'язуванням відповідного алгебраїчного рівняння.

І сьогодні ще не існує єдиної думки стосовно співвідношення в шкільному курсі математики арифметичного і алгебраїчного методів та їх ролі в розвитку розумової діяльності учнів. Перша позиція полягає в тому, що під час арифметичного методу розв'язування задач витрачається багато навчального часу, від вчителя і учня вимагається забагато марних зусиль. Б. Гнеденко, М. Лаврентьєв, А. Маркушевич та інші позиціонують алгебраїчний метод як основний для розв' язування текстових задач. 3'явилися психолого-педагогічні дослідження, в яких підкреслюється можливість введення буквеної символіки навіть «в дочисловому періоді» (В. Давидов), а також пропонується практика навчання алгебраїчному методу розв'язування задач без попереднього вивчення арифметичного методу (Ф. Боданський). Друга точка зору (І. Андронов, І.Богуславський, А. Левін та ін.) зосереджує свою увагу на визначенні арифметичного методу як першочергового в розвитку мислення учнів та в успішному оволодінні курсом математики. В цьому ми підтримує позицію авторів про те, що арифметичний метод розв'язування не тільки простих, але і складених задач повинен передувати використанню алгебраїчного метода.

Повертаючись до сучасного етапу розвитку математичної освіти в Україні, слід зазначити, що основним методом розв'язування задач в початковій школі залишається арифметичний метод. Арифметичний метод використовують для розв'язування задач, починаючи з 1-го класу і практично до 6-го класу. у 5-му класі відбувається перехід до алгебраїчного методу розв'язування задач, який стає головним для курсу математики 5-9 класів.

Коротко проаналізуємо зміст підручників математики 5-го класу (Істер, 2018; Мерзляк, Полонський \& Якір, 2018; Тарасенкова, Богатирьова, Бочко, Коломієць \& Сердюк, 2018) стосовно введення алгебраїчного методу розв'язування текстових задач. Річ у тому, що ці підручники розміщено на сайті «Шкільні підручники онлайн» й частіше за інші використовуються у школі. Насамперед зазначимо, що в чинній навчальній програмі 5-го класу (Навчальні програми, 2017) не вказується як само учень має навчитися розв'язувати текстові (сюжетні) задачі. Вимога вміння розв'язувати задачі за допомогою рівнянь з'являється у програмі математики 6-го класу. Може тому в сучасних підручниках для 5-го класу ми бачимо різний підхід до введення алгебраїчного методу розв'язування задач. Наприклад, у підручнику авторського колективу (Мерзляк, Полонський \& Якір, 2018) - розв'язування за допомогою невідомої $x$ з'являється в одному 3 прикладів параграфа «Ділення» у темі «Множення і ділення натуральних чисел»: «Нехай Івасик розв'язав $x$ задач з геометрії, тоді з алгебри він розв'язав $3 x$ задач». Вважати, що таке введення нового основного методу розв'язування 
природнє, й діти мають його зрозуміти, на наш погляд, - це завищене очікування. І, якщо вчитель не акцентує увагу на цьому методі та не приділить кілька уроків, щоб детально пояснити метод, наприклад, за допомогою малюнків чи схем (чому з'являється $x$, як складається рівняння), не відпрацює нові навички цілим набором задач, то може втратити одразу й бажання, й вміння учнів працювати із задачами взагалі. У підручнику (Істер, 2018) в темі «Натуральні числі і дії з ними» виділяється окремий параграф «Розв'язування текстових задач за допомогою рівнянь». Ніде не позначається, що розглядається новий метод розв'язування задач. І аналогічно: «Нехай у садку росло $x$ вишень, тоді яблунь було $x+4$ ». Однак, в цьому підручнику проводиться пропедевтична робота щодо введення алгебраїчного методу. Так, в параграфі «Додавання натуральних чисел» $€$ задачі (№ 141, 142, с. 23) типу «На одній з полиць $x$ книжок, а на другій на 5 менше», потрібно скласти буквений вираз до розв'язання задачі та обчислити його при певному значенні $x$. Потім у темі «Рівняння» учням пропонується розв'язати кілька задач за допомогою рівнянь (№№ 390, 391,392). Наприклад: «У корзині було кілька грибів. Після того як у неї поклали 25 грибів, їх стало 72. Скільки грибів було у корзині?» Проте, ця задача дуже швидко розв'язується арифметичним методом, тому вчителеві потрібно пояснити дітям, навіщо застосовувати складний метод розв'язування задачі, коли $€$ короткий і зрозумілий шлях для отримання розв'язку задачі. Діти в силу своїх вікових особливостей часто не можуть зрозуміти складного розв'язання задачі за допомогою рівняння, бо без складання рівняння справляються з розв'язуванням задачі набагато краще і швидше. I тільки в одному з зазначених підручників, а саме (Тарасенкова, Богатирьова, Бочко, Коломієць \& Сердюк, 2018), в параграфі «Типи задач та способи їх розв'язування» дається назва нового методу - «алгебраїчний» та старого - «арифметичний», а також наводяться приклади розв'язання обома методами задачі з однією величиною, з двома однойменними величинами, з трьома залежними величинами (на вартість, роботу та рух).

\section{ОБГОВОРЕННЯ}

Виходячи з власних спостережень та досвіду, обговорень з вчителями математики, вважаємо, що спроби одразу і повністю переключити учнів 5-го класу на алгебраїчний метод розв'язування задач вдаються невдалими. Дітям важким здається все, починаючи з необхідності щось замінювати на невідому $x$, потім шукати зв'язок невідомої $x з$ іншими величинами, складати рівняння, розв'язувати його і знов повертатися від $x$ до конкретних величин. Потрібно розв'язати багато однотипних задач, перш ніж з'являється навіть не розуміння, а просто навичка роботи з таким методом. I ще гарно, якщо під час цього діти не втрачають віру у власні сили й взагалі не перестають розв'язувати задачі. Не потрібно забувати, що дитина може пропустити за важливих обставин декілька уроків, а потім їй потрібно самій розібратися з матеріалом за підручником. Вважаємо, що саме арифметика має створити міцний фундамент для алгебри, перехід від арифметичного методу до алгебраїчного доцільно робити після досягнення певного рівня володіння арифметичним методом згідно вікових можливостей учнів.

\section{ВИСНОВКИ ТА ПЕРСПЕКТИВИ ПОДАЛЬШОГО ДОСЛІДЖЕННЯ}

Формування навичок роботи учня з алгебраїчним методом розв'язування текстових задач $є$ трудомістким та довгим процесом, як для учня, так і для вчителя. При цьому учень повинен демонструвати певний рівень володіння арифметичним методом розв'язування текстових задач. На нашу думку, у 5-му класі між арифметичним та алгебраїчним методом обов'язково треба проводити паралелі, щоб учні не вважали ці методи відірваними один від одного. Для цього можна користуватися малюнками, таблицями, діаграмами, графічним зображенням, показувати, що тут невідому величину ми будемо позначати через $x$, а тут замість шуканої величини ставити знак питання, демонструвати учням схожість етапів розв'язування задачі обома методами. Вважаємо, що у 5-6 класах потрібно обов'язково продовжувати розв'язувати задачі й арифметичним методом.

\section{Список використаних джерел}

1. Арнольд И.В. Принципы отбора и составления арифметических задач. Вопросы методики математики. Известия АПН РСФСР. М., 1946. Вып. 6. С. 7-28.

2. І Істер. О.С. Математика. 5 кл.: підручник для закладів загальної середньої освіти. 2-ге вид. Київ: Генеза, 2018. 288 с.

3. Мерзляк А. Г., Полонський В. Б., Якір М. С. Математика. 5 кл.: підручник для закладів загальної середньої освіти. 2ге вид. Харків: Гімназія, 2018. 272 с.

4. Навчальні програми для загальноосвітніх навчальних закладів України, опис ключових змін. 5-9 класи. Київ: Видавничий дім «Освіта», 2017. 56 с.

5. Навчальні програми для 5-9 класів загальноосвітніх навчальних закладів. URL: https://mon.gov.ua/ua/osvita/zagalnaserednya-osvita/navchalni-programi/navchalni-programi-5-9-klas

6. Скворцова С.О. Методична система навчання розв'язування сюжетних задач учнів початкових класів: монографія. Одеса: Астропринт, 2006. 696 с.

7. Тарасенкова Н. А., Богатирьова І. М., Бочко О. П., Коломієць О. М., Сердюк 3. О. Математика. 5 кл.: підручник для закладів загальної середньої освіти. 2-ге вид. К.: Видавничий дім «Освіта», 2018. 240 с.

8. Типова освітня програма для 1-2 класів закладів загальної середньої освіти. URL: https://nus.org.ua/news/opublikuvaly-typovi-osvitni-programy-dlya-1-2-klasiv-nush-dokumenty/

9. Типова освітня програма для 3-4 класів закладів загальної середньої освіти. URL: https://mon.gov.ua/ua/npa/prozatverdzhennya-tipovih-osvitnih-program-dlya-3-4-klasiv-zakladiv-zagalnoyi-serednoyi-osviti-1273

10. Шевченко И. Н. Арифметика: учебник для 5-6 классов восьмилетней и средней школы. 11-е изд. М.: Просвещение, 1966. $216 \mathrm{c}$. 


\section{References}

1. Arnol'd, Y.V. (1946). Pryntsypy otbora y sostavlenyya aryfmetycheskykh zadach. Voprosy metodyky matematyky. [The principles of selection and compilation of arithmetic problems. Questions of the methodology of mathematics]. Yzvestyya APN RSFSR. Moskva [in Russian].

2. Ister, O.S. (2018). Matematyka. 5 kl.: pidruchnyk dlya zakladiv zahal'noyi seredn'oyi osvity. 2-he vyd.[Mathematics. Grade 5: a textbook for general secondary education. 2nd type]. Kyiv: Heneza [in Ukrainian].

3. Merzlyak, A. H., Polons'kyy, V. B., Yakir, M. S. (2018). Matematyka. 5 kl.: pidruchnyk dlya zakladiv zahal'noyi seredn'oyi osvity. 2-he vyd.[ Mathematics. Grade 5: a textbook for general secondary education. 2nd type]. Kharkiv: Himnaziya [in Ukrainian].

4. Navchal'ni prohramy dlya zahal'noosvitnikh navchal'nykh zakladiv Ukrayiny, opys klyuchovykh zmin. 5-9 klasy.(2017). [Curricula for secondary schools of Ukraine, description of key changes. Grades 5-9.] Kyiv: Vydavnychyy dim "Osvita» [in Ukrainian].

5. Navchal'ni prohramy dlya 5-9 klasiv zahal'noosvitnikh navchal'nykh zakladiv . [ Curricula for grades 5-9 of secondary schools]. [Electronic source]- URL : https://mon.gov.ua/ua/osvita/zagalna-serednya-osvita/navchalni-programi/navchalni-programi5-9-klas [in Ukrainian].

6. Skvortsova, S.O. (2006) Metodychna systema navchannya rozvyazuvannya syuzhetnykh zadach uchniv pochatkovykh klasiv: monohrafiya. [Methodical system of teaching the solution of plot problems of primary school students: a monograph]. Odesa: Astroprynt [in Ukrainian].

7. Tarasenkova, N. A., Bohatyr'ova, I. M., Bochko, O. P., Kolomiyets, O. M., Serdyuk, Z. O. (2018). Matematyka. 5 kl.: pidruchnyk dlya zakladiv zahal'noyi seredn'oyi osvity. 2-he vyd. [Mathematics. Grade 5: a textbook for general secondary education. 2nd type]. Kyiv: Vydavnychyy dim «Osvita» [in Ukrainian].

8. Typova osvitnya prohrama dlya 1-2 klasiv zakladiv zahal'noyi seredn'oyi osvity. [ A typical educational program for 1-2 grades of general primary education]. [Electronic source]. - URL: https://nus.org.ua/news/opublikuvaly-typovi-osvitni-programydlya-1-2-klasiv-nush-dokumenty/ [in Ukrainian].

9. Typova osvitnya prohrama dlya 3-4 klasiv zakladiv zahal'noyi seredn'oyi osvity. [ A typical educational program for 3-4 grades of general primary education]. [Electronic source] - URL: https://mon.gov.ua/ua/npa/pro-zatverdzhennya-tipovih-osvitnihprogram-dlya-3-4-klasiv-zakladiv-zagalnoyi-serednoyi-osviti- 1273 [in Ukrainian].

10. Shevchenko, I. N. (1966). Arifmetika: uchebnik dlya 5-6 klassov vos'miletnej i srednej shkoly. 11-e izd. [ Arithmetic: a textbook for 5-6 grades of eight-year and secondary schools]. 11th ed. Moskva: Education [in Russian]

\section{SOME NOTES ON THE INTRODUCTION OF THE ALGEBRAIC METHOD OF SOLVING TEXT TASKS IN THE 5TH GRADE MATHEMATICS COURSE Olga Yakovlieva}

South Ukrainian National Pedagogical University named after K. D. Ushynsky, Ukraine Viktoriia Kaplun

School of general education №68, Ukraine

Tetyana Anisimova

School of general education №30, Ukraine

Abstract.

Formulation of the problem. Characterizing the educational content of mathematics course for 5-9 grades, we can say that text tasks occupy a significant place in it. The main methods of solving text task in the 5th grade are arithmetic and algebraic methods. The article considers the ratio of arithmetic and algebraic methods in the school course of 5th grade mathematics, their role in the development of students' thinking and the corresponding content of 5th grade mathematics textbooks.

Materials and methods. Methods of analysis, synthesis, comparison, description of the obtained research results, generalization are used. Theoretical research methods related to the analysis of current mathematics curricula, 5th grade mathematics textbooks, relevant information sources were used. Own pedagogical experience and observations are generalized.

Results. The article discusses the main methods of solving text problems in the course of mathematics of the 5th grade. It is noted that the development of the formation of skills to solve text problems moves from the arithmetic method in primary school to a predominantly algebraic method in the 5th grade of secondary school. It was found that in the textbooks of the 5th grade the introduction of the algebraic method of solving problems differs significantly.

Conclusions. Based on our own experience, discussions with math teachers of the above issues, we can say that attempts to immediately and completely switch 5th grade students to the algebraic method of solving problems are unsuccessful. Forming a 5th grade student's skills in working with the algebraic method is a long and time-consuming process for both the student and the teacher. Parallels should be drawn between the arithmetic and algebraic methods of solving problems so that students do not consider these methods to be detached from each other. We believe that in grades 5-6 it is necessary to continue to solve problems with both methods.

Keywords: Basic school, text tasks, arithmetic method, algebraic method. 